\title{
The Scope of Academic Freedom Right and the Situation of Scientists in Poland
}

\author{
Monika Stachowiak-Kudła ${ }^{1}$ (D)
}

Received: 28 March 2020 / Accepted: 23 November 2021 / Published online: 5 December 2021

(c) The Author(s) 2021

\begin{abstract}
The implementation of academic freedom can be difficult both for policymakers and university authorities. A good example of these difficulties is the case of Poland. These difficulties stem from three factors: a weak legal tradition of academic freedom, a lack of legal definition of this freedom and the transition of Polish universities from the collegial to the managerial management model. This article analyzes the impact of these three factors on the situation of Polish scientists. It is very plausible that the introduction of a legal definition of academic freedom to the Law on Higher Education and Science could mitigate the tendency to limit academic freedom in Poland. Such a definition would make it difficult for governments, faculty and university authorities to interfere with this right and make it easier for researchers to assert their rights in court.
\end{abstract}

Keywords Academic freedom - Freedom of scientific research · Freedom of teaching $\cdot$ Managerial management model $\cdot$ Poland

\section{Introduction}

Academic freedom is understood as "the right, without constriction by prescribed doctrine, to freedom of teaching and discussion, freedom in carrying out research and disseminating and publishing the results thereof, freedom to express freely their opinion about the institution or system in which they work, freedom from institutional censorship and freedom to participate in professional or representative academic bodies" (UNESCO, 1997). Academic freedom is a fundamental right protected by Article 13 of the Charter of Fundamental Rights of the European Union and within the text of the constitutions of many states, in which it appears in the form of freedom of scientific research and freedom of teaching. Academic freedom

Monika Stachowiak-Kudła

mstachowiak@poczta.fm

1 Faculty of Administration and Social Sciences, Warsaw University of Technology, Poland, street Plac Politechniki 1, 00-661 Warsaw, Poland 
is a defensive right, and therefore one that protects scientific and teaching activities against the interference of the state and other authorities, including university and faculty authorities. Academic freedom also protects academics from other academics (Menand, 1996). The defensive aspect of academic freedom is often taken up in literature (Enders et al., 2013; Wight, 2020), in particular in the context of knowledge creation (Beiter et al., 2016; Karran, 2009; Rittberger \& Richardson, 2019).

The contextual conditions surrounding academic freedom and its specific practices are different in each country. The differences result from factors related to different political cultures, educational cultures and state-university relations (Marginson, 2014). Sometimes the complex social and institutional characteristics of a country are not conducive to ensuring adequate conditions for observing academic freedom. For instance, we observe difficulties in ensuring adequate conditions for the implementation of academic freedom in countries such as Canada (Woodhouse, 2019), Hungary (Bárd, 2018; Baskerville, 2019) and Turkey (Öztürk, 2018). Difficulties also occur in Poland, in particular in providing appropriate conditions for interdisciplinary research and local research.

This article indicates how the implementation of academic freedom at Polish universities is affected by the insufficient legal tradition of academic freedom, the lack of a legal definition of this freedom and the transition of Polish universities from the collegial to the managerial management model. This paper analyzes these issues beginning with an analysis of the higher education legislation issued in Poland since 1918, jurisprudence of the constitutional court, as well as an analysis of actions taken by the decision-makers and universities themselves. The final section briefly concludes the findings of the paper.

\section{Legal Tradition of Academic Freedom}

Poland has a relatively short tradition of academic freedom warranty. This stems from the fact that it was only in 1918 (after 123 years) that Poland regained its independence. Moreover, the period of real socialism after the Second World War, lasting until 1989, negatively affected the guarantee of this freedom.

In the nineteenth century, Poland was divided by three empires: Prussia, Austria and Russia. During this time, the issues of higher education were governed by the legislation of Austria and Russia. Under the Prussian partition, there were no Polish universities, and only the Jagiellonian University in Cracow in the Austrian partition enjoyed relative independence. The other three universities: Vilnius University, Lviv University and the University of Warsaw-were not autonomous (Bartnicka, 1986). After regaining independence in 1918, Polish universities were reformed based on the principles of the Humboldtian model (Scott, 2002). The guarantee of freedom of scientific research and teaching appeared in the provisions of both Polish Constitutions adopted at that time: from March 17, 1921 and from April 23, 1935. It was also confirmed in the Act of 13 July 1920 (Article 6) and the Act of 15 March 1933 (Article 1(1)): the Law on Academic Schools.

During the period of real socialism that followed World War II, academic freedom was limited. The statement that "scientific research is free" was included in 
the Decree of 28 October 1947 on the Organization of Science and Higher Education, but with the proviso that "creative work is under the special protection of the state" (Article 1 and 7). The guarantee of freedom of scientific research disappeared with the adoption of the Act of 15 December 1951: the Law on Higher Education and Science. Not only did it not appear as a fundamental right in the Constitution adopted on July 22, 1952, but it was also limited by the obligation to conduct scientific research in a specific direction. It was assumed that science was to be based on "the achievements of leading human thought and progressive Polish thought—-science in service of the nation" (Article 63), which led to the conclusion that researchers are not allowed to go beyond the interests of the nation, which was determined outside of the universities (Sobczak, 2007). The Act of 5 November 1958: the Law on Higher Education also ideologized science, stating that "universities are actively involved in the construction and strengthening of socialism in the Polish People's Republic by conducting creative scientific research" (Article 1). Ideological referrals disappeared with the adoption of the Act of 4 May 1982: the Law on Higher Education. At that time, freedom of scientific research was restored (Article 2(3)). Since the restoration of democracy in 1989, all laws concerning higher education have guaranteed freedom of scientific research and freedom to teach. ${ }^{1}$

At present, Poland's Constitution of April 7, 1997 guarantees academic freedom (Article 73) and freedom of expression (Article 54), with which the freedom of scientific research is closely related. It also guarantees higher education autonomy (Article 70 (5)) which is an institutional academic freedom warranty. In the Constitution, we can also find the right to access public information (Article 61) and the right to information on the state and protection of the environment (Article 74 (3)), which is particularly important for implementing academic freedom in the area of social and natural sciences. The Constitution determines the possible field of restricting academic freedom. In Article 31 (3) it is indicated that "[a]ny limitation upon the exercise of constitutional freedoms and rights may be imposed only by a statute, and only when necessary in a democratic state for the protection of its security or public order, or to protect the natural environment, health or public morals, or the freedoms and rights of other persons. Such limitations shall not violate the essence of freedoms and rights". These constitutional guarantees for academic freedom have been assessed very highly in a comparative study on the level of academic freedom in Europe (Karran et al., 2017, p. 229).

\footnotetext{
${ }^{1}$ See: Act of 12 September 1990. The Law on Higher Education, Article 2(1); Act of 27 July 2005. The Law on Higher Education, Article 4(2); Act of 3 July 2018. The Law on Higher Education and Science, Article 3.
} 


\section{Academic Freedom as a Right}

Academic freedom in Poland, unlike for example in Czechia, Belgium, Germany and Portugal, ${ }^{2}$ does not have a legal definition. The Higher Education and Science Act of July 3, 2018 does not define freedom of scientific research or freedom to teach. The Minister of Education and Science proposed to extend academic freedom in a so-called "freedom package" at the end of 2020. Despite this, the Conference of Rectors of Academic Schools in Poland, which is a representative body composed of rectors of universities, has not agreed to increase academic freedom in Poland in this way. ${ }^{3}$

The lack of a legal definition means that in the event of a dispute, the Constitutional Court of Poland determines what is the essence of these freedoms and what is not. This court interprets the essence of freedom of scientific research as the freedom to choose subjects for scientific research, freedom to choose methodology and freedom to publish the results. In Poland "the freedom to access all information that may be needed for the research" is also an element of the freedom of scientific research. "Freedom to teach, in turn, includes the freedom of systematic transfer of knowledge to other people" (Wyrok z dnia 12 kwietnia 2012 r., sygn. akt. K 30/10, at para III.2.1).

The Constitutional Court (Wyrok z dnia 7 lutego 2006 r., sygn. akt SK 45/04, at para III.8, and Wyrok z dnia 12 kwietnia 2012 r., sygn. akt K 30/10, at para III.2.1) indicates three important aspects of academic freedom. First, academic freedom must "protect the individual and other right entities from ungrounded state interference in the subject and methods of scientific research and in the content and methods of teaching". Second, the Constitutional Court (Wyrok z dnia 8 listopada 2000 r., sygn. SK 18/99, at para III.1, and Wyrok z dnia 7 lutego 2006 r., sygn. akt. SK 45/04, at para III.8) underlines the special relationship between academic freedom and university autonomy: "the autonomy of higher education institutions aims to create conditions for these institutions to optimally implement their tasks in the field of research and teaching". Third, the Constitutional Court (Wyrok z dnia 25 listopada 2008 r., sygn. akt K 5/08, at para V.4.1 and V.5.2.4) states that academic freedom may be limited in individual manifestations of its implementation due to the rights and freedoms of other people. This court explains that conducting scientific research cannot be a cover for violating dignity, privacy or freedom of conscience and religion of other people. At the same time, the Constitutional Court of Poland

\footnotetext{
2 See: Legal definition of academic freedom in Czechia: Act of 22 April 1998. The Law on Higher Education Institutions and on Amendments and Supplements of Other Acts, § 4; in Belgium: Decree of March 31, 2004 Defining Higher Education, Promoting its Integration into the European Space of Higher Education and Refinancing the Universities, Article 67; in Germany: Framework law on higher education from April 12th, 1999 with the latest amendment in 2019, § 4 (2 and 3); in Portugal: Constitution of the Portuguese Republic, April 2, 1976, Article 42.

3 In terms of the Minister of Education and Science's proposal see: https://www.gov.pl/web/edukacjai-nauka/pakiet-wolnosci-akademickiej. Within the scope of objection by the Conference of Rectors of Academic Schools see: https://www.krasp.org.pl/pl/Aktualnosci/?id=21487/Korespondencja_Przew odniczacego_KRASP_do_Ministra_Edukacji_i_Nauki_w_sprawie_tzw Pakietu_Wolnosci_Akade mickiej_.
} 
recognizes the freedom of scientific research as a right weaker than the right to private life (Wyrok z dnia 25 listopada 2008 r., sygn. akt K 5/08; see also: StachowiakKudła, 2021).

The view of the Polish Constitutional Court is not isolated. The constitutional courts of other European countries have also highlighted these three aspects of academic freedom (Stachowiak-Kudła, 2021). The literature which refers to the first aspect indicates that a lack of limitations in conducting scientific and teaching activities is the basic way in which academic freedom is also understood in other European countries (Karran, 2007) and in other parts of the world e.g., in Australia (Akerlind \& Kayrooz, 2003) and the United States (Misco \& Patterson, 2007). Regarding the second aspect of academic freedom, Quinn and Levine (2014, p. 913) state that the work of scientists by "its nature produces challenges and tensions", and therefore scientists may be at risk of conflict with governments and other authorities (Karran, 2009). For these reasons, scientists need institutional protection of their rights (Altbach, 2001). Regarding the third aspect of academic freedom, Hayes (2009) distinguishes legal and non-legal arguments for limiting academic freedom. The legal arguments result from constitutions or acts. In particular, a so-called "limitation clause" is typical for constitutions of European countries (Kumm, 2007). Therefore, the mentioned Article 31 of the Polish Constitution is not an exception.

The Constitution of Poland indicates (Article 73) that academic freedom is available to everyone and-as indicated by the Constitutional Court (Wyrok z dnia 28 kwietnia 2009 r., sygn. akt K 27/07, at para III.4.4 and III.4.2)—does not have to be associated with an academic community. However, "the freedom of artistic creation, freedom of scientific research, freedom to publish research results and freedom of teaching are particularly important for academics". Due to the fact that everyone is entitled to academic freedom, Polish law protects against excessive entry into the sphere of other constitutionally protected rights and freedoms. For instance, access to documents collected by the Institute of National Remembrance requires a recommendation from a researcher or an independent scientific institution (Act of June 29, 2007 amending the act on the Institute of National Remembrance-Commission for the Prosecution of Crimes against the Polish Nation, Article 36). This requirement is not classified as a limitation of academic freedom, because it protects the privacy of the people whom the archives concern (see: Constitutional Court of Poland, wyrok z dnia 25 listopada 2008 r., sygn. akt K 5/08).

Finally, in Poland, great importance is attached to the reliability of scientific research, and a particular emphasis is placed on historical truth. Hence, the interference of public authorities in academic freedom is considered permissible only in the case of the so-called 'Holocaust denial', which is a particular combination of objective falsehood and subjective bad faith (Garlicki, 2001). Special attachment to the reliability of historical research is also manifested in the adoption of a special Act of 18 December 1998 on the Institute of National Remembrance-Commission for the Prosecution of Crimes against the Polish Nation. Under Article 55 of this Act, public denial of the Nazi crimes, the Communist crimes and other crimes against peace, humanity or war is an ex officio offence punishable by a fine or imprisonment of up to 3 years. 


\section{Obstacles to the Implementation of Academic Freedom}

Currently, there are some tendencies to limit academic freedom in Poland. The new Act of 3 July 2018: the Law on Higher Education and Science switched the collegial management model to the managerial management model. The rectors' competences were significantly increased and a new university body was established - the university council, at least $50 \%$ of which is composed of people from outside of the university's community (Article 18-19 and 23). The motivation for the change to the managerial model was a concern for the effective management of the traditional collegial structure. It was introduced because the competitiveness of universities was perceived to be insufficient by the decision makers (Dakowska, 2015). Specifically, Polish higher education experiences a problem of low university-based-knowledge-production (Kwiek, 2012; Parteka \& Wolszczak-Derlacz, 2013), which is even lower in non-public higher education institutions (Antonowicz, Kohoutek, et al., 2017; Antonowicz, Kwiek, et al., 2017). The level of commercialization of research is also very low (Wiśniewska \& Lewicki, 2018), and the main reason for this stems from the excessive teaching-orientation of universities in the 1990-2005 period (Kwiek, 2012), where even the evaluation of higher education institutions in various rankings was biased towards education rather than science (Rocki, 2005). Hence, the higher education reforms since 2005 have been aimed at re-embedding the research mission of universities (Dobbins, 2017, see also: Spychalska-Stasiak \& Ostrowicka, 2020). In order to improve scientific excellence, a number of instruments have been introduced, including bibliometric measures of excellence (Antonowicz, Kohoutek, et al., 2017; Antonowicz, Kwiek, et al., 2017; Korytkowski \& Kulczycki, 2019).

The managerial model of university management can pose a threat to academic freedom for four reasons. First, a characteristic feature of the managerial model is the existence of a university body that is appointed from outside the academic community and which has decisive competences. William G. Tierney (2001) and Carole Kayrooz and Paul Preston (2002) have argued that the presence of such a body, especially when it is composed of people associated with public administration, can place emphasis on conducting "safe" research, where controversial research will be considered undesirable. However, as Terence Karran points out, knowledge "is created by challenging orthodox ideas and beliefs" (2009, p. 191). In order to protect Polish universities from this threat, the Act of 3 July 2018: the Law on Higher Education and Science prohibits the recruitment of persons employed in public administration to the university council (Article 265(4)).

Second, the introduction of the managerial model of university management can pose a threat to academic freedom because it strengthens the traditional intracommunity focus around traditional disciplines. Mehdi Safavi and Lars Håkanson (2018) proved that this in turn negatively affects interdisciplinary research, where academic freedom is also the "freedom to work across disciplines" (Herbert \& Tienari, 2013, p. 166). The conduct of interdisciplinary research is endangered by the implementation of new laws. The decision-makers decided to assign journals to scientific disciplines and introduced an obligation to submit statements 
about the represented field of science or art and the scientific or artistic discipline in which research will be conducted in advance (Act of 3 July 2018: the Law on Higher Education and Science, Articles 267(3) and 265(13)). Scientific disciplines were assigned to journals based on the information from Scopus, the Science Citation Index Expanded, the Social Sciences Citation Index, the Arts and Humanities Citation Index and the Emerging Sources Citation Index. A Polish scientist must in advance predict the discipline and the journal which will accept the results of his or her scientific work. However, there are studies that are difficult to ascribe to one specific discipline. Although a Polish scientist may change the discipline declared earlier, such an action may be detrimental to the academic unit in which she works, especially when the scientific unit is small. Pursuant to Article 265(4) of the Act of 3 July 2018: the Law on Higher Education and Science, the evaluation of a discipline shall be carried out where the number of scientists at least meets 12, calculated on a full-time employment basis. Therefore, a researcher in a given discipline employed at a small university has a limited right to change discipline because it can cause the number of research staff to drop below the limit of 12 scientists. A change in the number of scientists in a given discipline below 12 results in non-evaluation of a discipline and, consequently, the reduction of public funding for the university. The problem is urgent, as the authorities of some universities announce new competitions for a position, requiring from future employee the publishing of their scientific research only in journals assigned to the pre-specified disciplines. The legal incentives for conducting interdisciplinary research remain insufficient in this situation. ${ }^{4}$

Third, the introduction of the managerial approach to university governance may pose a threat to academic freedom because it places great emphasis on scientists being "excellent at an international level". In turn, publishing in worldwide journals, requires research which solves problems relevant at a global level. A Polish scientist may publish his or her research results wherever he or she wants, but in the evaluation of scientific units the publications in journals from the ministerial list are assessed as more valuable. The ministerial list was introduced to change the publication patterns of scientists, where journals are ranked based on a percentile value of the impact factor, and allocated 200, 140, 70, 40 or 20 points. The majority of Polish journals are not listed in these databases, so a financial support program for 500 Polish scientific journals has been introduced. As a consequence, Polish journals which have not been assessed as distinguished are valued at 5 points. ${ }^{5}$ In

\footnotetext{
${ }^{4}$ For example, a 20-point higher premium is set for scientific activities in the case of interdisciplinary scientific research: Regulation of the Minister of Science and Higher Education of 22 February 2019 on the evaluation of the quality of scientific activities, $\$ 23(8)$.

5 The manner in which lists of publications of scientific monographs and journals and peer-reviewed materials from international conferences are constructed is determined by the Minister by regulation (Act of 3 July 2018: The Law on Higher Education and Science Article 267 (2 and 3)). The following rule is in force, the Regulation of the Minister of Science and Higher Education of 7 November 2018, on the preparation of lists of publications of scientific monographs and scientific journals and peer-reviewed materials from international conferences, $\S 8$. The number of points for journals is defined in the Regulation of the Minister of Science and Higher Education of 22 February 2019 on the evaluation of the quality of scientific activities, $\S 12(1)$. The list is available at: http://www.bip.nauka.gov.pl/wykaz-czaso pism-naukowych/
} 
practice, publications in journals outside the official list may prompt the rector to terminate the employment of the academic teacher if she collects too few points to get a positive individual assessment period (Act of 3 July 2018: the Law on Higher Education and Science, Article 267(1)). The number of points collected also affects the university's entitlement to confer doctoral degrees (Article 185(1)) and postdoctoral degrees (Article 218) and, finally, the amount of funds received by universities (Article 387(3), 388). Therefore, the burden of responsibility for the scientific quality of the discipline pursued at a given university is transferred to the researcher, who, being aware of the fact that she is a part of a team, remains under strong pressure from the university authorities and colleagues to produce papers on topics that can be published in international scientific journals. It should be noted that some research is only suitable for publication to a domestic audience, because it focuses on local problems, and the results of local research rarely interest an international audience. Therefore, some researchers who concentrate on local problems are perceived as making insufficient scientific achievements and they are moved to teaching positions or even dismissed. The change to a teaching position involves a higher number of teaching hours without a change in remuneration (Act of 3 July 2018: the Law on Higher Education and Science, Article 127(2)). These additional teaching hours are often unrelated to the specialization of researchers and they require additional preparation. Furthermore, the ministerial list favors publications in English which reduces the Polish language to a subordinate role and makes the knowledge of English a necessary skill at Polish universities (Odrowaz-Coates, 2020).

Fourth, the managerial model of university management favors neo-liberal politics. Neo-liberalism is based on the assumption that the market can replace the democratic state as the primary producer of cultural logic and value (Harvey, 2009; Lynch, 2006; Szadkowski, 2017; Yokoyama, 2019). This market view of citizenship is antithetical to state-guaranteed rights in education (Mullen, et al., 2013; Tienken, 2013) including academic freedom. In practice, universities are being asked to produce commercially oriented professionals rather than public-interest professionals (Hanlon, 2000). In turn, scientists have to conduct research of global importance and there is no incentive to engage in the public sphere (Lynch, 2006; Szadkowski, 2017). In Poland, the funding of universities is strongly related to the results of disciplines, and institutions with a special "research" status cannot have any discipline with low achievements (otherwise they do not receive additional funding). All of these factors mean that scientists in Poland face a dilemma; they must decide whether to conduct research that serves the Polish public interest or to publish in prestigious journals, for example, those which are indexed in the Web of Science. It is difficult to achieve both of these goals, especially in fields such as the humanities and social sciences. If academics choose the latter option, there will be less involvement of scientists in public debate and there will be "no incentives to publicly dissent or engage within the very institutions that are charged with the task of dissent and engagement" (Lynch, 2006). Moreover, in a highly marketed higher educational system there is a serious threat to critical thought (Webster, 2004). In economically unequal societies, only academics in faculties with sufficient resources can make choices, and academics in "poorer" faculties have no choice. This fact is not changed much by the Act of 3 July 2018: the Law on Higher Education and Science 
(Preamble), which stipulates that "universities and other research institutions carry out a mission of particular importance for the state and nation: they make a key contribution to the innovation of the economy, contribute to the development of culture and shape moral standards in public life". There is no continuity between university goals. The aim of university is not only the production of knowledge or the acquisition of competencies, but also to offer "opportunities to become attentive to what is going on today" (Simons \& Masschelein, 2009, p. 15). Therefore, the university authorities in Poland, together with Minister of Education and Science, should work out legal and organizational solutions that will restate this balance.

\section{Discussion}

In Poland, the tradition of academic freedom was interrupted by periods of undemocratic rule. After 1989, Poland reformed its higher education system towards increasing university autonomy and guaranteeing academic freedom. The constitutional guarantees of academic freedom were of particular importance in democratic transitions. The difficult history of Poland, in particular the experiences of the partitions, World War II and the period of "real socialism", contributed to a very broad, compared to European conditions, scope of academic freedom. What distinguishes the understanding of academic freedom in Poland from that in many other European countries is the granting of this freedom to everyone, and not associating it with an academic community. Finally, a strong attachment to historical truth is characteristic for Poland. It manifests in adding to the list of crimes the crime against truth.

Recent higher education reforms prove that it is not easy to guarantee academic freedom at the right level. The transition to the managerial approach to university governance has caused difficulties in providing appropriate conditions for interdisciplinary research, local research and those serving the public interest. If public interests are to be served, academic freedom cannot be seen as just a right. As Alexis Gibbs argues, it should be viewed as an act "in the best interests of others, the future of others and other futures" (2016, p. 184).

The work of scientists should be defined by increasing demands for accountability and effectiveness (Stachowiak-Kudła \& Kudła, 2017) but "[i]n cultures of measurement, audits, comparisons, segregation and stratification", we should keep assessment in moderation (Black et al., 2017). Academic freedom includes the freedom to choose the subject of research, and this subject may have only local significance. Academic freedom encompasses the freedom to choose research methods and it does not preclude their use in interdisciplinary research. Academic freedom also consists of the freedom to choose how and where the results are presented. An important aspect of academic freedom is the pursuit of teaching and conducting research without the fear of external interference or sanctions, not only from governments but also from the authorities of a university. It should be emphasized that universities were granted autonomy in order to protect academic freedom.

The problems discussed here can at least be partially mitigated by the introduction of a legal definition of academic freedom to the Act of 3 July 2018: the Law on Higher Education and Science. Such a definition would make it difficult for 
governments, faculty and university authorities to interfere with this right and make it easier for researchers to assert their rights in court.

Acknowledgements The author gratefully acknowledges the support of the Polish National Research Council (NCN) through the 2016/23/D/HS5/00206 Grant.

Open Access This article is licensed under a Creative Commons Attribution 4.0 International License, which permits use, sharing, adaptation, distribution and reproduction in any medium or format, as long as you give appropriate credit to the original author(s) and the source, provide a link to the Creative Commons licence, and indicate if changes were made. The images or other third party material in this article are included in the article's Creative Commons licence, unless indicated otherwise in a credit line to the material. If material is not included in the article's Creative Commons licence and your intended use is not permitted by statutory regulation or exceeds the permitted use, you will need to obtain permission directly from the copyright holder. To view a copy of this licence, visit http://creativecommons.org/licen ses/by/4.0/.

\section{References}

Act of 13 July 1920. The Law on Academic Schools. Retrieved from http://isap.sejm.gov.pl/isap.nsf/ download.xsp/WDU19200720494/O/D19200494.pdf

Act of 15 March 1933. The Law on Academic Schools. Retrieved from http://isap.sejm.gov.pl/isap.nsf/ download.xsp/WDU19330290247/O/D19330247.pdf

Act of 15 December 1951. The Law on Higher Education and Science. Retrieved from http://isap.sejm. gov.pl/isap.nsf/download.xsp/WDU19520060038/O/D19520038.pdf

Act of 5 November 1958. The Law on Higher Education. Retrieved from http://isap.sejm.gov.pl/isap.nsf/ download.xsp/WDU19580680336/O/D19580336.pdf

Act of 4 May 1982. The Law on Higher Education. Retrieved from http://isap.sejm.gov.pl/isap.nsf/downl oad.xsp/WDU19820140113/O/D19820113.pdf

Act of 12 September 1990. The Law on Higher Education. Retrieved from http://isap.sejm.gov.pl/isap. nsf/download.xsp/WDU19900650385/U/D19900385Lj.pdf

Act of 22 April 1998. The Law on Higher Education Institutions and on Amendments and Supplements of Other Acts. Retrieved from https://www.msmt.cz/uploads/odbor_30/TF/Legislativa_a_metodicke_ pokyny/Novela_2016/Zakon_o_vysokych_skolach_AJ.pdf

Act of 27 July 2005. The Law on Higher Education. Retrieved from http://isap.sejm.gov.pl/isap.nsf/downl oad.xsp/WDU20051641365/T/D20051365L.pdf

Act of 29 June 2007 amending the act on the Institute of National Remembrance-Commission for the Prosecution of Crimes against the Polish Nation. Retrieved from http://isap.sejm.gov.pl/isap.nsf/ download.xsp/WDU20071400983/T/D20070983L.pdf

Act of 3 July 2018. The Law on Higher Education and Science. Retrieved from http://isap.sejm.gov.pl/ isap.nsf/download.xsp/WDU20180001669/U/D20181669Lj.pdf

Akerlind, G. S., \& Kayrooz, C. (2003). Understanding academic freedom: The views of social scientists. Higher Education Research and Development, 22(3), 327-344.

Altbach, F. (2001). Academic freedom: International realities and challenges. Higher Education, 41, 205-219.

Antonowicz, D., Kohoutek, J., Pinheiro, R., \& Hladchenko, M. (2017). The roads of 'excellence' in Central and Eastern Europe. European Educational Research Journal, 16(5), 547-567.

Antonowicz, D., Kwiek, M., \& Westerheijden, D. F. (2017). The government response to the private sector expansion in Poland. In H. de Boer, J. File, J. Huisman, M. Seeber, M. Vukasovic, \& D. F. Westerheijden (Eds.), Policy Analysis of Structural reforms in higher education (pp. 119-138). Springer.

Bárd, P. (2018). The rule of law and academic freedom or the lack of it in Hungary. European Political Science. https://doi.org/10.1057/s41304-018-0171-x 
Bartnicka K. (1986). Przemiany w administracji polskich uniwersytetów na przełomie XVIII i XIX w. Rozprawy z Dziejów Oświaty, 29, 3-36. [Transformations in the administration of Polish universities at the turn of the 18th and 19th centuries.]

Baskerville, S. (2019). Academic freedom and the Central European University. Academic Questions, 32, 257-262.

Beiter, K. D., Karran, T., \& Appiagyei-Atua, K. (2016). Academic freedom and its protection in the law of European States: Measuring an international human right. European Journal of Comparative Law and Governance, 3(3), 254-345.

Black, A. L., Crimmins, G., \& Jones, J. K. (2017). Reducing the drag: Creating v formations through slow scholarship and story. In S. Riddle, M. K. Harmes, \& P. A. Danaher (Eds.), Producing pleasure in the contemporary university (pp. 137-156). Springer.

Constitution of the Republic of Poland, March 17, 1921. Retrieved from http://libr.sejm.gov.pl/tek01/txt/ $\mathrm{kpol} / \mathrm{e} 1921 . \mathrm{html}$

Constitution of the Republic of Poland, April 23, 1935. Retrieved from http://libr.sejm.gov.pl/tek01/txt/ $\mathrm{kpol} / \mathrm{e} 1935 . \mathrm{html}$

Constitution of the Polish People's Republic of 22 July 1952. Retrieved from http://libr.sejm.gov.pl/tek01/ txt/kpol/e1952.html

Constitution of the Republic of Poland of 2 April 1997. Retrieved from https://www.sejm.gov.pl/prawo/ konst/angielski/kon1.htm

Constitution of the Portuguese Republic of 25 April 1974. Retrieved from https://dre.pt/constitution-ofthe-portuguese-republic

Constitutional Court of Poland, wyrok z 8 listopada 2000 r., sygn. SK 18/99. Retrieved from http://isap. sejm.gov.pl/isap.nsf/download.xsp/WDU20001011091/T/D20001091TK.pdf

Constitutional Court of Poland, wyrok z dnia 7 lutego 2006 r., sygn. akt SK 45/04. Retrieved from http:// isap.sejm.gov.pl/isap.nsf/download.xsp/WDU20060250192/T/D20060192TK.pdf

Constitutional Court of Poland, wyrok z dnia 25 listopada 2008 r., sygn. akt K 5/08. Retrieved from http://isap.sejm.gov.pl/isap.nsf/download.xsp/WDU20082161380/T/D20081380TK.pdf

Constitutional Court of Poland, wyrok z dnia 28 kwietnia 2009 r., sygn. akt K 27/07. Retrieved from http://isap.sejm.gov.pl/isap.nsf/download.xsp/WDU20090680584/T/D20090584TK.pdf

Constitutional Court of Poland, wyrok z dnia 12 kwietnia 2012 r., sygn. akt. K 30/10, Retrieved from http://isap.sejm.gov.pl/isap.nsf/download.xsp/WDU20120000431/T/D20120431TK.pdf

Dakowska, D. (2015). Between competition imperative and Europeanization: The case of higher education reform in Poland. Higher Education, 69(1), 129-141.

Decree of 28 October 1947 on the organization of science and higher education enacted on accessed from: http://isap.sejm.gov.pl/isap.nsf/download.xsp/WDU19470660415/O/D19470415.pdf

Decree of 31 March 2004 Defining Higher Education, Promoting its Integration into the European Space of Higher Education and Refinancing the Universities. Retrieved from https://www.gallilex.cfwb.be/ document/pdf/28769_017.pdf

Dobbins, M. (2017). Exploring higher education governance in Poland and Romania: Re-convergence after divergence? European Educational Research Journal, 16(5), 684-704.

Enders, J., De Boer, H., \& Weyer, E. (2013). Regulatory autonomy and performance: The reform of higher education re-visited. Higher Education, 65(1), 5-23.

Framework law on higher education from April 12th, 1999 with the latest amendment in 2019. Retrieved from https://www.bgbl.de/xaver/bgbl/start.xav\#_bgbl_\%2F\%2F*\%5B\%40attr_id\%3D $\% 27 \mathrm{bgb}$ 1199s0018.pdf\%27\%5D_1625228706999

Garlicki L. (2001). Konstytucja Rzeczypospolitej Polskiej. Komentarz, Warszawa [Commentary to the Constitution of the Republic of Poland].

Gibbs, A. (2016). Academic freedom in international higher education: Right or responsibility? Ethics and Education, 11(2), 175-185.

Hanlon, G. (2000). Sacking the New Jerusalem? The New Right, Social Democracy and Professional Identities. Sociological Research Online, 5(1). Retrieved from http://www.socresonline.org.uk/5/1/ hanlon.html

Harvey, D. (2009). A brief history of neoliberalism. Oxford University Press.

Hayes, D. (2009). Academic freedom and the diminished subject. British Journal of Educational Studies, 57(2), 127-145.

Herbert, A., \& Tienari, J. (2013). Transplanting tenure and the (re)construction of academic freedoms. Studies in Higher Education, 38(2), 157-173. 
Karran, T. (2007). Academic freedom in Europe: A preliminary comparative analysis. Higher Education Policy, 20(3), 289-313.

Karran, T. (2009). Academic freedom in Europe: Reviewing Unesco's, Recommendation. British Journal of Educational Studies, 57(2), 191-215.

Karran, T., Beiter, K., \& Appiagyei-Atua, K. (2017). Measuring academic freedom in Europe: A criterion referenced approach. Policy Reviews in Higher Education, 11(2), 209-239.

Kayrooz, C., \& Preston, P. (2002). Academic freedom: Impressions of Australian social scientists. Minerva, 40(1), 341-358.

Korytkowski, P., \& Kulczycki, E. (2019). Examining how country-level science policy shapes publication patterns: The case of Poland. Scientometrics, 119, 1519-1543.

Kumm, M. (2007). Political liberalism and the structures of rights: on the place and limits of the proportionality requirement. In G. Pavlakos (Ed.), Law, rights, discourse. The legal philosophy of Robert Alexy (pp. 131-166). Hart.

Kwiek, M. (2012). Changing higher education policies: From the deinstitutionalization to the reinstitutionalization of the research mission in Polish universities. Science and Public Policy, 39, 641-654.

Lynch, K. (2006). Neo-liberalism and marketisation: The implications for higher education. European Educational Research Journal, 5(1), 1-17.

Marginson, S. (2014). Academic freedom: A global comparative approach. Frontiers of Education in China, 9, 24-41. https://doi.org/10.1007/BF03397000

Menand, L. (1996). The limits of academic freedom. In L. Menand (Ed.), The Future of Academic Freedom (pp. 3-20). University of Chicago Press.

Misco, T., \& Patterson, N. C. (2007). A study of pre-service teachers' conceptualizations of academic freedom and controversial issues. Theory and Research in Social Education, 35(4), 520-550.

Mullen, C. A., Samier, E. A., Brindley, S., English, P. W., \& Carr, N. K. (2013). An epistemic frame analysis of neoliberal culture and politics in the US, UK, and the UAE. Interchange, 43, 187-228.

Odrowaz-Coates, A. (2020). Chaos theory and the neoliberal English-based dimension of the Polish higher education reforms 2018/2019. Education as Change, 24(1), 01-19.

Öztürk, A. E. (2018). Lack of self-confidence of the authoritarian regimes and academic freedom: The case of İşar Gözaydın from Turkey. European Political Science. https://doi.org/10.1057/ s41304-018-0170-y

Parteka, A., \& Wolszczak-Derlacz, J. (2013). Dynamics of productivity in higher education: Cross-European evidence based on bootstrapped Malmquist indices. Journal of Productivity Analysis, 40(1), 67-82.

Quinn, R., \& Levine, J. (2014). Intellectual-HRDs and claims for academic freedom under human rights law. International Journal of Human Rights, 18(7-8), 898-920.

Rittberger, B., \& Richardson, J. (2019). What happens when we do not defend academic freedom. Journal of European Public Policy, 26(3), 324.

Regulation of the Minister of Science and Higher Education of 7 November 2018 on the preparation of lists of publications of scientific monographs and scientific journals and peer-reviewed materials from international conferences. Retrieved from http://isap.sejm.gov.pl/isap.nsf/download.xsp/ WDU20180002152/O/D20182152.pdf

Regulation of the Minister of Science and Higher Education of 22 February 2019 on the evaluation of the quality of scientific activities. Retrieved from http://isap.sejm.gov.pl/isap.nsf/download.xsp/WDU20 190000392/O/D20190392.pdf

Rocki, M. (2005). Statistical and mathematical aspects of ranking: Lessons from Poland. Higher Education in Europe, 30(2), 173-181.

Safavi, M., \& Håkanson, L. (2018). Advancing theory on knowledge governance in universities: A case study of a higher education merger. Studies in Higher Education, 43(3), 500-523.

Scott, P. (2002). Reflections on the reform of higher education in Central and Eastern Europe. Higher Education in Europe, 27(1-2), 137-152.

Simons, M., \& Masschelein, J. (2009). Towards the idea of a World University. Interchange, 40, 1-23. https://doi.org/10.1007/s10780-009-9087-2

Sobczak J. (2007). Wolność badań naukowych: Standardy europejskie i rzeczywistość polska. Nauka $i$ Szkolnictwo Wyższe, 30(2), 53-74. [Freedom of scientific research - European standards and Polish reality].

Spychalska-Stasiak, J., \& Ostrowicka, H. (2020). Continuity and change: The academic teacher-student relationships in the discourse on the higher education reform in Poland. Qualitative Report, 25, 31-55. 
Stachowiak-Kudła, M., \& Kudła, J. (2017). Financial regulations and the diversification of funding sources in higher education institutions: Selected European experiences. Studies in Higher Education, 42(9), 1718-1735.

Stachowiak-Kudła, M. (2021). Academic freedom as a source of rights' violations: A European perspective. Higher Education. https://doi.org/10.1007/s10734-021-00718-3

Szadkowski, K. (2017). The university of the common: Beyond the contradictions of higher education subsumed under capital. In M. Izak, M. Kostera, \& M. Zawadzki (Eds.), The future of university education. Palgrave Critical University Studies.

Tienken, C. H. (2013). Neoliberalism, social darwinism, and consumerism masquerading as school reform. Interchange, 43, 295-316.

Tierney, W. G. (2001). Academic freedom and organisational identity. Australian Universities Review, 44(1), 7-14.

UNESCO. (1997). Recommendation concerning the status of higher-education teaching personnel. Retrieved November 11, from https://unesdoc.unesco.org/ark:/48223/pf0000113234.page=2

Webster, F. (2004). Cultural Studies and Sociology at and after the closure of the Birmingham School. Cultural Studies, 18(6), 847-862.

Wight, S. (2020). Critical dogmatism: Academic freedom confronts moral and epistemological certainty. Political Studies Review. https://doi.org/10.1177/1478929920942069

Wiśniewska, U., \& Lewicki, J. (2018). The level of competence of young researchers and the knowledgebased economy: The challenges of doctoral education in Poland. In J. J. Ferreira, A. Fayolle, V. Ratten, \& M. Raposo (Eds.), Entrepreneurial universities. Collaboration, education and policies (pp. 105-134). Edward Elgar Publishing.

Woodhouse, H. (2019). Academic freedom and collegial governance under threat at a Canadian university. Interchange, 50, 113-121.

Yokoyama, K. (2019). The effect of changing capital-labour relations on the universities: Some interpretations of the 2008 financial crisis. Interchange, 50, 137-154.

Publisher's Note Springer Nature remains neutral with regard to jurisdictional claims in published maps and institutional affiliations. 